\section{Omkring Riisager-året 1997}

\author{
Af førstebibliotekar Niels Krabbe
}

Artiklen er en sterkt udvidet version af forfatterens presentation på Bogmessen $i$ Forum i november 1997 af bogen Knudåge Riisager, Symfonien er død, - musiken leve, Det Kongelige Bibliotek 1997.

$\mathrm{M}$ an kan godt smile lidt af alt halløjet omkring komponisters runde år. Men i mindst to forskellige henseender er der penge i det. For det første er der gode indtjeningsmuligheder for forlags- og pladebranchen $\mathrm{i}$ at udsende diverse jubilæumsudgivelser - meget ofte i form af veltjent og udslidt stof i ny indpakning. For det andet er der muligheder for at hente gode penge til prisværdige formål hos fonde og andre private eller halvoffentlige tilskudsgivere; pengene flyder i lidt rigere mål, når de målrettes mod disse runde år, og skam fă den, der tænker ilde herom.

1 997 havde sine prominente musikjubilarer, som blev behørigt fejret ude i Europa, vigtigst blandt dem Schubert og Brahms, førstnævnte i 200året for hans fødsel, sidstnævnte i 100året for hans død. I forvejen er disse komponisters liv og værk belyst i en sådan grad, at det kan være svært at finde nyt stof $i$ anledning af jubilæet uden at skulle gå endog meget langt ud i periferien. Og det må man så gøre, eller også må man som antydet vælge at garne- ringen snarere end indholdet kommer $\mathrm{i}$ centrum. Rent galt bliver det, når det drejer sig om de allerstørste: Bach, Beethoven og Mozart.

Anderledes forholder det sig med komponister, som af den ene eller anden grund har været oversete: her er der mulighed for ikke blot at markere det runde år men også benytte anledningen til en revurdering af den pågældende kunstners betydning med deraf følgende markedsføring af produktionen. Netop 100-året for en komponists fødsel er velegnet til en sådan vurdering: kildematerialet til hans liv og hans musik er i stort omfang ordnet og tilgængeligt, der er stadig personer, som på den ene eller den anden måde har haft berøring med komponisten i levende live og tiden har lagt en vis afstand til biografien og værket på en måde, som gør en historisk placering mulig.

Disse vilkår passer godt på i

hvert fald den ene af de to danske komponister, hvis 100-års fødselsdag er blevet markeret i 1997, nemlig Knudåge Riisager. Den anden er Jørgen Bentzon. Musiklivet i almindelighed og Det Kongelige Bibliotek i særdeleshed valgte at lægge hovedindsatsen omkring Riisager. Selvom det altid er svært at sammenligne to jævnaldrende komponisters betydning, er der i dette tilfælde saglige grunde til en sådan prioritering. Set i det lange perspektiv er Riisager vel overhovedet en af de betydeligste skikkelser $\mathrm{i}$ det 20. århundredes danske musikhistorie i kraft af summen sine tre virkefelter: som komponist, skribent og administrator. Mens musiklivet - det vil i denne sammenhæng primært sige Danmarks 
Radio og det Kongelige Teater - koncentrerede sine Riisager-fremstød omkring selve fødselsdagen i marts 1997, ydede Det Kongelige Bibliotek sin hovedindsats i efteråret 1997 med udgivelse af Riisagers Musik for bleserkvintet', en samling af Riisagers essays ${ }^{2}$ og ikke mindst med Riisager-udstillingen på Musikhistorisk Museum. Til disse initiativer kan føjes tre markante CD’er på plademærkerne Chandos og dacapo med en række betydelige kammermusik- og orkesterværker, herunder Etudes, Qarrtsiluni, Slaraffenland, Concertino for trompet og strygere og førnævnte Musik for bleserkvintet op. 16. Og så blev der forresten sat en mindeplade op på muren ud for Frederiksberg Bredegade nr. 5 , huset, som Riisagers fader lod bygge $\mathrm{i}$ år 1900, og hvor komponisten tilbragte 15 år af sin barndom, et stenkast fra Frederiksberg Rådhus, fra hvis tårn man $i$ en række år kunne høre de af Riisager komponerede kvarter- og timeslag.

Det er nærliggende at spørge om der nu tegner sig et andet billede af Riisager end før 100-års fejringen. Som ballet-komponist har han altid været kendt, ikke mindst i kraft af samarbejdet med førende koreografer som Harald Lander, Birgit Cullberg og Flemming Flindt, og Riisagers og Landers Etudes har længe været et af balletrepertoirets slagnumre. Til gengæld har der været langt mellem opførelser af hans instrumental- og kammermusik. Også som skribent har han været synlig i kraft af essaysamlingen Det usynlige Monster fra 1957. Dette kendskab kan nu nuanceres og udvides gennem det nye udvalg af hans talrige litterære skrifter med den

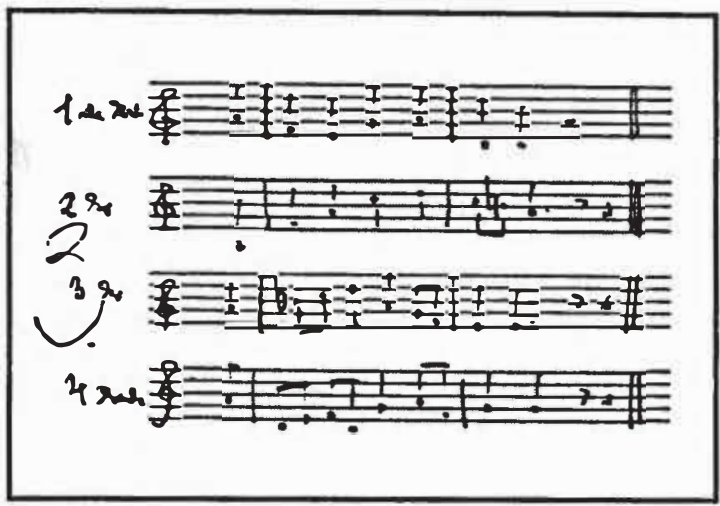

Kvarterslagene for rådhusklokkerne på Frederiksberg Radhus, komponeret af Knudåge Riisager.

dertil hørende bibliografi over hans imponerende produktion af op mod 400 artikler $\mathrm{i}$ aviser, ugeblade og fagtidsskrifter. Måske er det således ikke et nyt billede, der tegner sig, men måske nok et mere fuldstandigt.

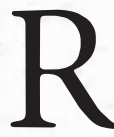

iisager tilhører generationen født o. 1890 , hvis fremmeste repræsentanter foruden ham selv var Jørgen Bentzon, Finn Høffding, Ebbe Hammerik og Flemming Weiss, komponister, som dukkede op på den hjemlige musikalske scene i slutningen af 20'erne - altså i det årti, hvor Carl Nielsen for alvor havde markeret sig som den ubetinget dominerende skikkelse i danske musikliv. Det hører med til en af de sejlivede myter omkring Carl Nielsen, at vægten af hans personlighed og tyngden $i$ hans musik lagde en skygge over anden musik i hans samtid. Det er nok et meget høj grad netop en myte, skabt af Carl Nielsen receptionen, som den udviklede sig efter hans død.

For Riisagers vedkommende er der i hvert fald ikke tale om nogen form 
for skyggevirkning fra Carl Nielsen, ligeså lidt som der er tale om nogen erklæret musikalsk inspiration, endsige ${ }^{-}$ lærer-elev-forhold. Riisager ydede tidligt Nielsen fuld anerkendelse (og gentog den ved senere lejligheder), men orienterede sig, som det fremgår nedenfor, i øvrigt mod andre forbilleder.

Der er således ikke megen mening $i$ at sammenligne disse to, når det drejer sig om deres musik, men nok, når det drejer sig om den litterære produktion, et område, hvor de uomtvisteligt er de to mest betydningsfulde og indflydelsesrige danske komponister fra dette århundrede. Parallellerne er iøjnefaldende, men også forskellene. Begge udsendte de selv på deres 60 -års dag et lille udvalg af egne essays og kronikker, Carl Nielsen med Levende Musik i 1925 og Knudåge Riisager med Det Usynlige Mønster i 1957. For begges vedkommende udgør disse artikler kun en forsvindende lille del af deres samlede skriftlige produktion og tegner derfor kun et ufuldstændigt billede af deres musikæstetiske univers. Men her hører ligheden også op. Både i indholdet af dette univers og i den betydning det har haft for eftertidens vurdering af dets ophavsmænd er der iøjnefaldende forskelle. For Nielsens vedkommende har Levende Musik dannet grundlag for en hel æxsetik, som har været brugt som målestok for hans egen musik og for musik af hans samtidige og efterkommere. Stikord som enkelhed, umiddelbarhed, naturlighed og ukunstlethed er nøglebegreber i denne æstetik, og med sådanne begreber ved hånden har man dyrket én bestemt side af Carl Nielsens musik og afvist an- dre sider, ligesom man har brugt Levende Musik til at legitimere påstanden om Carl Nielsens lukkethed overfor udefra kommende strømninger. Meget i hans biografi og værk dementerer en sådan opfattelse, og på dette felt har hans essaysamling måske gjort mere skade end gavn.

A nderledes med Riisagers litterære produktion. For det første dannede Riisager ikke skole, således som Nielsen gjorde det. Selvom han i en vis forstand "fyldte" lige så meget som Carl Nielsen, havde han naturligvis ikke samme position som komponist. Til gengæld er hans horisont som skribent nok videre end den Nielsen'ske - han vover så at sige noget mere. Det er en blanding af gammelborgerlig konservatisme og ungdommelig radikalitet, der fascinerer hos Riisager og som gør det vanskeligt at sætte ham i bås. I mellemkrigstiden kom han ganske vist i berøring med flere af de i øvrigt meget forskellige de toneangivende "ismer" $\mathrm{i}$ kulturlivet, hvoraf her skal fremhæves de venstreradikale kultur- og samfundskritikere på den ene side og folkemusikskolebevægelsen, som den lanceredes af Jørgen Bentzon og Finn Høffding på den anden, ligesom han for en stund tilsluttede sig kredsen af proselytter for den nye jazzmusik. Men ingen af disse grupperinger kunne tælle ham blandt deres faste "medlemmer". Mest overraskende er nok hans korte, men betydningsfulde engagement i Forsøgsscenen, teaterfraktionen i den stærkt kommunistisk inspirerede Monde-gruppe, som netop er blevet indgående beskrevet $\mathrm{i}$ 
den nyligt udkomne monografi af Olaf Harsløf $\mathrm{f}^{4}$. Riisager sad i Forsogscenens bestyrelse i årene omkring 1930 (og virkede her sammen med folk som Broby Johansen, Erling Brene, Oluf Rosenkrantz o.a. ), deltog i en række arrangementer og skrev $\mathrm{i}$ institutionens blad af samme navn. I dette regi gjorde han et kraftigt fremstød for Arnold Schønbergs musik, der på den tid var lidet kendt i Danmark, om end han allerede i 1923 havde dirigeret sin kammersymfoni i København; dels skrev han en introduktion til Schønberg i Forsøgsscenen ${ }^{5}$, dels foranledigede han Schønbergs Kvintet for blesere op. 26 - traditionelt regnet for et af komponistens allerførste offentliggjorte dodekafone værker - opført ved en koncert i Forsogsscenen i februar 1930.

K nudåge Riisagers spændvidde fremgår af bredden $i$ hans litterære produktion. Han kommer vidt omkring både i musiklivet og i kulturlivet i almindelighed. Overalt udtrykker han sig fyndigt og med vægt, og overalt tager han standpunkt. Dertil kommer, at han - ligesom Carl Nielsen er en fremragende stilist. En slags Credo står at læse i artiklen Ny skonbed. Musikalske randbemarkninger fra 1927, hvor det som et tidligt litterært sidestykke til en af hans sidste kompositioner Til Apollon (1972) hedder:

"Tiden bærer i sig forenkling, et frisk syn på livet og en aktiv, bekræftende aand. Vor tid er en lys-tid, dens livssyn er et lys-syn. Industrialismen har lært os maskinens blaanende poesi og skønheden i staalets elastiske spænding.
Maskinen er en levende organisme, et støt arbejdende væsen med rolige aandedrag. Disse det daglige livs oplevelser gaar ind i den skabende bevidsthed som motiver, og de digtes om af den frie fantasi. De geometriske figurers fængslende mystik og matematikkens vidt favnende tankebygning sætter den kunstnerisk omformede evne i rytmiske svingninger, der afføder sjælelige begivenheder og bliver vor tids kunst. Den menneskelige sjæl er en skælvende kompasnaal, som svinger for at komme i leje i et stadigt ligevægtspunkt. Det er denne svingen kunsten er udtryk for og derfor beror den på de menneskelige problemer. En kaktus og en lilje ejer skønhedens under, men hver paa sin maade"6.

$\mathrm{B}$ landt de mange temaer, han behandler i sine op mod 400 artikler og notitser, har især to bidt sig fast i eftertidens bevidsthed: opgøret med den overleverede symfoniske form og modstillingen af det galliske og det germanske i musikken med klar stillingtagen til fordel for det galliske. Begge emner lancerer han i hver sin programmatiske artikel for derefter senere at vende tilbage til dem i forskellige andre sammenhænge.

Artiklen fra 1940 med den provokerende titel Symfonien er dod musiken leve gav genlyd i musikdebatten og xggede til modsigelse fra blandt andre Vagn Holmboe og Sven Erik Tarp? At historien skulle vise, at Riisager havde uret i titlens profeti, ændrer ikke ved udsagnets betydning, da det blev fremsat. Det er et opgør med symfonien som "et 


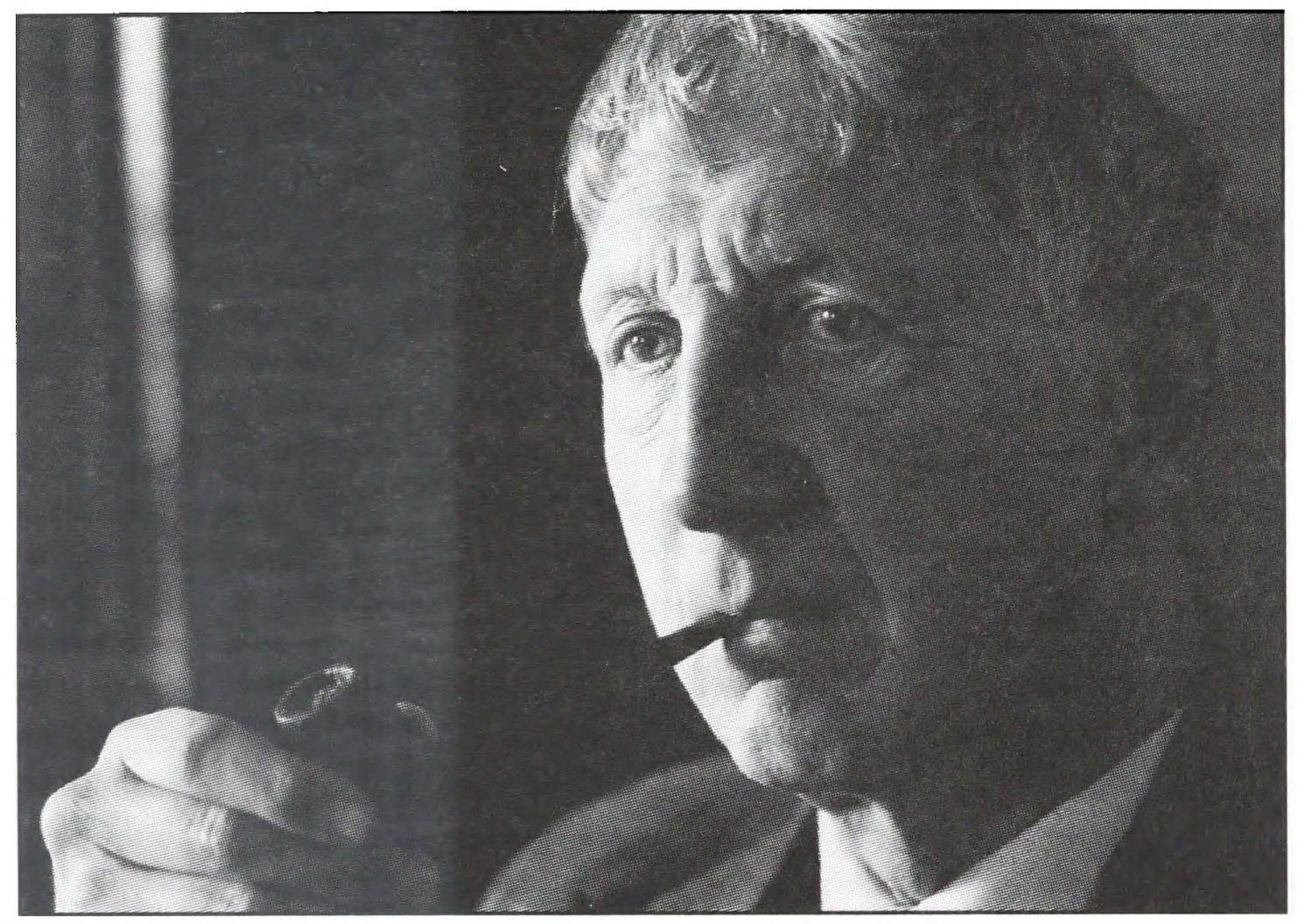

filosofisk anliggende", som ramme om "sonateformens tematiske kamp mellem to verdener i modsætning til den moderne tanke om det tematiske materiales samtidighed", som det, der modarbejder tidens ideal om "klarhed og knaphed". Eller sagt med andre ord: opgøret mod de sidste rester af den Beethovenske symfoniske "fortælling" om forsoningens mulighed, der bedst beskrives gennem udtrykket per aspera ad astra.

I den anden programartikel, Gallisk og germansk, trykt i Nationaltidende i 1924 taler den kun 27-årige komponist frejdigt Roma midt imod ${ }^{8}$. Her drager Riisager i felten mod den gennem de foregående 200 år dominerende tyske indflydelse på dansk musik og musikliv til fordel for en fransk inspi- ration, som han netop selv havde mødt under sit studieophold i Paris. I en lige linje fra F.L.Ae. Kunzen og J.E. Hartmann (begge indvandret fra Tyskland) over næste generation med C.E.F. Weyse og D.F. Kuhlau (ligeledes begge født $\mathrm{i}$ Tyskland), via de to nationale, men også tysk inspirerede guldalderkomponister N.W. Gade og I.P.E. Hartmann og frem til Carl Nielsen havde dansk musik stået i gæld til tyske forbilleder. Det var dette hegemoni, Riisager brød med, muligvis i stærkere vendinger, end der var dækning for også hos ham selv, men som et forfriskende og livgivende indlæg i debatten så at sige:

"Ligesom på den virkelige Valplads mødtes to vidt forskellige Aandsretninger ogsaa paa den musikalske 
Verdens Arena. Gallisk og germansk brødes i en voldsom Brænding. Den salte Bølge slog mod den udhulede Klippe. Det er resultatet af denne Strid, vi er Vidne til."

Den germanske tonekunst karakteriseres herefter ved sin "...manglende Sans for det formale, Ubehændighed parret med overanstrengt Fantasi, Hang til Grublen og Krav om Systematisering og etiske Værdier. Følelse erstattes af bævende Sentimentalitet".

Og videre hedder det:

"Publikum blev saaledes opdraget til at kræve stedse mere. Ligesom Morfinisten, der kræver stedse stærkere Gift. Øret forlangte stærkere og stærkere Paavirkning. Sansen var afstumpet for de fine sjælelige Strenge, som klinger rent og gennemsigtigt i Kammermusiken."

Her lades ikke meget håb tilbage! Over for dette stilles den galliske musik, der lever op til det klassiske skønhedsideal.

“Dette lægger Hovedvægten paa Helhedsindtrykket, paa Formens Fasthed, paa Liniernes harmoniske Samspil og paa de let gennemskuelige Tankers klare Ligevægtsforhold".

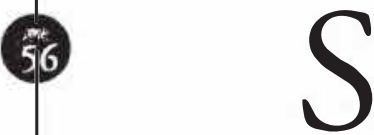

kal der drages en enkelt konsekvens af Riisager-året 1997 måtte det være, at det nu er tiden at skrive den store, samlende Riisager-monografi. I kraft af Riisagers centrale placering $\mathrm{i}$ dansk musikliv $i$ årtierne før og efter 2. verdenskrig ville en sådan monografi $\mathrm{i}$ meget høj grad samtidig blive en kritisk vurdering af en række tendenser og strømninger i dansk musikhistorie $i$ en periode, der måske er kommet lidt $\mathrm{i}$ klemme mellem på den ene side Carl Nielsen-era'en og på den anden gennembruddet for Darmstadt-modernismen og dens væsen: en diskussion af gennemslaget i Danmark af fænomener som jazz, folkemusikbevægelse, neoklassicisme, ny saglighed, opgøret med traditionens musikalske udtryk og formverden o.m.a., men også en belysning af etableringen af en række nationale musikinstitutioner, som har spillet en afgørende rolle i periodens musikpolitik, herunder ikke mindst DUT og Dansk Komponistforening. I disse strukturer indfletter Riisager sig på central vis $\mathrm{i}$ kraft af sit organisatoriske engagement, sin stærke personlighed og sin produktion $\mathrm{i}$ ord og toner. Hvad det musikpolitiske- og musikæstetiske angår specielt vedrørende den i denne sammenhæng afgørende mellemkrigstid - er der gjort talrige forarbejder, som en Riisager-monografi kan trække på: udover de mange litteraturhistoriske og socialhistoriske undersøgelser skal på det rent musikhistoriske område fremhæves arbejder af Michal Fjeldsøe, Peder Kaj Pedersen og Claus Røllum Larsen?.

Men hertil kommer naturligvis beskrivelsen af Riisagers biografi og produktion ${ }^{10}$. Her er der, som antydet ovenfor, nok at øse af. Dels var komponisten meget tidlig en offentlig person, hvis liv og færden derfor i høj grad fremgår af tilgængelige kilder, dels kan meget biografisk stof hentes i foreningsarkiver og hos komponistens efterkommere. Den samlede vurdering af musikken derimod må afvente en nøjere kortlægning af produktionen. Hovedparten af Riisagers værker findes i Det Kongelige Bibliotek, 
men det må formodes, at der stadig gemmer sig ukendte værker i privat eje. Ganske vist udkom i i anledning af komponistens 70 -års dag en værkregistrant $^{11}$, men den er langtfra udtømmende, og der forestår derfor et betydeligt arbejde med henblik på at opstille en fuldstændig kronologisk registrant over værkerne. Først når det er gjort, kan en seriøs værkanalyse sætte ind.

Kunstnerbiografien som genre har fået et voldsomt opsving inden for de seneste år, udmøntet såvel praktisk som teoretisk. Et kærnepunkt har i denne sammenhæng altid været forholdet mellem biografi og værk: i hviket omfang kan musikken (som det her drejer sig om) leve op til det populistiske krav om at være en direkte afledning af biografien, altså kravet om overensstemmelse mellem liv og værk, som i hvert fald

\section{Noter}

$1 \quad$ Knudåge Riisager, Musik for bleserkvintet (Dansk musik fra Det Kongelige Biblioteks Samlinger 4, udgivet af Birgit Bjørnum, 1997)

2 Knudåge Riisager, Symfonien er dod musiken leve og andre essays, udgivet af Niels Krabbe, Det Kongelige Bibliotek 1997

3 Chandos. Chan 9432, dacapo 8.224081 og 8.224082

4 Olaf Harsløf, Monde-Gruppen. Kampen om kunsten og socialismen i Danmark 19281932, 1997, s. $305 \mathrm{ff}$.

5 "Schønberg - og så videre", Forsogsscenen 21 8, 1930. Allerede i 1919 - $\mathrm{i}$ en artikel $\mathrm{i}$ Tilskueren - havde Riisager introduceret - Schønberg (jvf. Riisager-bibliografien i Knudage Riisager, Symfonien er dod, op.cit.

6. Symfonien er dod, op.cit s. 41-42 siden det store Mozart-boom med Hildesheimers biografi og Milos Formans film Amadeus har været på dagsordenen. For Riisagers vedkommende skal man ikke vente at finde en sådan kobling. Allerede det forhold, at han en stor del af sit live så at sige var "fritidskomponist", udelukker en sådan tilgang, men mere afgørende er det, at Riisagers æstetik er uendelig fjern fra en tro på kunstens mulighed for at være en udkomponering af træk fra kunstnerens privatsfære. Dermed være naturligvis ikke hævdet, at det er meningsløst at se musikken i samspil med sin egen tid. Det er netop det, der bliver opgaven for en Riisager-monografi og det, der kunne gøre opgaven interessant og perspektivrig.

Riisager-året 1997 har givet sit til at lægge stoffet tilrette.

7 Gengivet i Symfonien er dod, op.cit. s. 1521

* Gengivet i Symfonien er dod, op.cit. s. 2631

" Peder Kaj Pedersen, Trak af den musikpedagogiske debat i mellemkrigstiden, Aarhus 1976. Claus Røllum Larsen, Dansk instrumentalmusik ca. 1910-1935, upubl. ph.d.afhandling, København 1995. Michael Fjeldsøe, ingangværende ph.d. arbejde med arbejdstitlen Den ny musik $i$ dansk musikliv 1920-1940

11) På Musikhistorisk Museum i København findes fjerde korrektur til en aldrig udgivet bog om Knudåge Riisager fra 1953, skrevet af museets daværende arkivar Sigurd Berg

11 Knudage Riisagers Kompositioner. En fortegnelse ved Sigurd Berg og Svend Bruhns, København 1967 